\title{
Phenological Development, Grain Growth Rate, Seedling Vigour and Yield Relationships in Wheat Cultivars under Normal Sown Irrigated Conditions
}

\author{
Kavita Rani ${ }^{1 *}$, Vikram Singh ${ }^{1}$, V. S. Mor ${ }^{2}$, M. S. Dalal ${ }^{1}$ and Ram Niwas ${ }^{3}$ \\ ${ }^{1}$ Department of Genetics and Plant Breeding, CCSHAU, Hisar, India \\ ${ }^{2}$ Seed Science and Technology, CCSHAU, Hisar, India \\ ${ }^{3}$ Department of Mathematics Statistics, CCSHAU, Hisar, India \\ *Corresponding author
}

\section{A B S T R A C T}

\begin{tabular}{|l|}
\hline Ke y w or d s \\
$\begin{array}{l}\text { Phenologial development, } \\
\text { Grain growth rate, } \\
\text { seedling vigour }\end{array}$ \\
\hline Article Info \\
\hline $\begin{array}{l}\text { Accepted: } \\
\text { 22 May } 2018 \\
\text { Available Online: } \\
\text { 10 June } 2018\end{array}$ \\
\hline
\end{tabular}

Keywords

Phenologial development, th rate,

Article Info

\section{Introduction}

Wheat is a self-pollinating annual plant plays a major role among the few crop species being extensively grown as staple food sources in the world. In India wheat is cultivated on 30.72mha, with a production $97.44 \mathrm{mt}$ and productivity $31.72 q /$ ha. Haryana with 11.14 $\mathrm{mt}$ production, $2.54 \mathrm{~m}$ ha area and $4.39 \mathrm{t} / \mathrm{ha}$ productivity ranks third in the country (Anonymous, 2017). World demand for wheat is estimated to 840 to 1000 million tons by 2020. The need and importance of wheat is increasing day by day due to increasing in the human population. The option for increasing wheat production by expanding area under its cultivation has already been exploited almost to its maximum. Therefore, continuous efforts are required to develop high yielding and disease resistance wheat varieties. Thus, development of high yielding wheat cultivars has always been a major objective of wheat breeding programmes throughout the world (Bhutta, 2006). For development of high yielding varieties, the proper plant architecture and duration of plants are of paramount importance.

Grain yield in wheat is a complex trait and is the product of several contributing factors affecting it directly or indirectly. For improving any plant character through selection, first the estimation of genetic parameters must be made. The grain yield and yield components of wheat are very much affected by the genotype and the environment. 
Therefore, as new cultivars are being produced by breeding, the breeders study the relationships between yield and its components.

Wheat grain yield is also limited by source or sink or both (Evans et al., 1975). The results of different studies by manipulating sourcesink relationships during grain filling through removing leaves or grains, and shading have shown inconsistent conclusions (Slafer and Savin, 1994; Cruz-Aguado et al., 1999). This inconsistency reflects the genotype and environment interactions in the availability of assimilate for grain growth (Ma et al., 1990). A better understanding of the relationship between plant development and yield may assist breeders to simultaneously improve heat tolerance and yield in wheat. The primary objective of this research was to study physiomorphological characters, rate and duration of grain filling and physiological parameters that may be related to yield, and the relationships among them for utilization as selection criteria in breeding program.

\section{Materials and Methods}

A field experiment was conducted under irrigated condition at CCSHAU, Hisar, India during winter (Rabi) season 2013-2014. This location typically experiences moderate drought during the pre and post-anthesis periods. The soil at the location was clay loam with a $\mathrm{pH}$ 7.1-8. The experimental materials comprised of genetically diverse 40 wheat genotypes whose description is given in Table.1. Out of forty genotypes, 10 genotypes were recommended for timely sown irrigated condition, 5 were recommended for late sown irrigated condition, 3 varieties for early sown conditions out of which two for rainfed conditions and one for restricted irrigation conditions and 22 advance breeding lines. Observations for all the traits were recorded on five randomly selected plants for each genotype in each replication. The data were recorded for days to $50 \%$ heading (DH), days to anthesis (DA), plant height (PH), flag leaf length (FL), flag leaf width (FB), flag leaf area (FLA), number of tillers per meter (T), spike length (SL), main spike weight (SW), spikelets per spike (SPS), grains per spike (GPS), grains weight per spike $(\mathrm{GW})$, grain length (GL), grain breadth (GB), grain growth rate (GGR) at 14, 21 and 28 days after anthesis, biological yield (BY), grain yield (GY), thousand grains weight (TGW), harvest index (HI), standard germination test (GM), seedling length (SLg), seedling dry weight (SD), vigour index-I (V-I), vigour index-II (VII), seed density (Sd), plant straight height (SH) at 30 days, plant drooping height (Dr.H) at 30 days, field emergence index (FE) and seedling establishment (FS). Analysis of the observations recorded on different characters was carried out as per the standard procedure

\section{Results and Discussion}

All the parameters exhibited significant variability. The mean sum of squares due to genotype was highly significant for most of the character under study (Table 2).

Wheat in Haryana, experienced favorable moisture conditions along with low temperatures during vegetative stages (December-Mid February), while the reproductive stage (late February-March) experienced the moisture stress condition with high temperature (Laxman et al., 2014). The optimum temperature for wheat anthesis and grain filling ranges from 12 to $22^{\circ} \mathrm{C}$. Exposure to temperatures above this can significantly reduce grain yield (Tewolde et al., 2006; Fisher, 2007). Linear increases in temperature started by the third week of February and reached approximately $25{ }^{0} \mathrm{C}$ by the end of February (Fig1). Heading and maturity are important traits that are related to the adaptation of wheat cultivars under prevalent 
field conditions in particular areas. Under normal environmental conditions, early heading and late maturity permits a long grain-filling period, which leads to higher grain yields in cereals (Bidinger et al., 1997; Sanchez et al., 2002). Post-anthesis heat stress in wheat induces several physiological effect which eventually result in smaller grain weight due to reduced grain filling period and starch synthesis duration or the combined effect of both (Hasan and Ahmed, 2005). Among 40 genotypes WH 1105, WH 1138 and HD 2967 had the highest grain yield per plant 1150.0, 1136.7 and $1103.3 \mathrm{~g} / \mathrm{plot}$ respectively, under the prevailing environmental conditions of the region. These genotypes took 93.3, 95.6 and 96 days, respectively, for 50\% heading and 102.3, 102.7 and 104.3 days, respectively, for anthesis. These genotypes escape late-season drought and high temperature stress.

Grain growth and development are affected by heat stress. This is because heat stress limits remobilization of photo assimilates into the developing grains (Wang et al., 2012). Furthermore, heat stress can also shorten the duration of grain growth, which in turn reduces grain mass (Dias and Lidon, 2009). The genotypes WH 1105, WH 1138 and WH 1126 have moderate to high grain growth rate at 14 days $(6.80,6.53$ and $7.50 \mathrm{~g} / \mathrm{gr} / \mathrm{day} \times 10-$ 4respectively) with high grain yield 1150.0, 1136.7 and 1026.7 g/plot respectively (Fig.2). Genotypes attain higher test weight by maintaining higher grain growth rates under high temperature condition (Fig.3). The genotypes PBW 343, WH 1178 have high 1000-test weight (48.70g and $48.50 \mathrm{~g}$ resp.) with high grain growth rate at 14 days with low grain growth rate at 21 and 28 days. Wheat cultivar that can fill their grain quickly may have an advantage in environments with short, hot and dry, grain filling period. So, to avoid stress, they complete their life cycle earlier (Whan et al., 1996). However, grain yields were low when the days to $50 \%$ heading was either too short or too long viz., WH 1163 and WH 1025 with have 86.67 and 108.00 days to $50 \%$ heading with $803.3 \mathrm{~g}$ and $886.7 \mathrm{~g} / \mathrm{plot}$ grain yield. This suggests that proper balancing of these developmental traits, such as pre-heading period, grain filling period and grain growth rate may facilitate a more desirable combination, which results in higher grain yield.

One of the important aspects for quality grain production is rapid emergence and good seedling establishment in the field. Therefore, quick and uniform field emergence is essential to achieve high yield in annual crops (Yari et al., 2010). Seed germination and seedling growth traits are extremely important factors in determining yield (Rauf et al., 2007). HD 2967 and WH 1126 have the highest vigour index-II and seedling establishment percentage (15124.43, 13477.33 and $84.00 \%$, $82.33 \%$ respectively). These genotypes have high grain yield $1103.3 \mathrm{~g}$ and $1026.7 \mathrm{~g}$ per plot as well as germination percentage (95.00 and 97.67 respectively). (Likhachev, 1973) Concluded that emergence depended more on seedling vigour than on germination energy in wheat and rye. Vigour index-I was highest in WH1179 and germination percentage (98.00) with moderate seedling establishment percentage (72.00) and grain yield (903.3g/plot).

The grain yield was positively correlated with number of tillers per meter $\left(0.866^{* *}\right)$, flag leaf length $\left(0.815^{* *}\right)$, flag leaf area $\left(0.689^{* *}\right)$, harvest index $\left(0.568^{* *}\right)$, grain weight per spike $\left(0.224^{* *}\right), 1000$ grain weight $\left(0.198^{*}\right)$ and grain growth rate at 28 days $\left(0.227^{*}\right)$ (Table 4). Similar results found for number of effective tillers, by (Bhutto et al., 2016; Kumar et al., 2013) and (Nukasani et al., 2013). 
Fig.1 Maximum and minimum temperature at the time of grain growth period

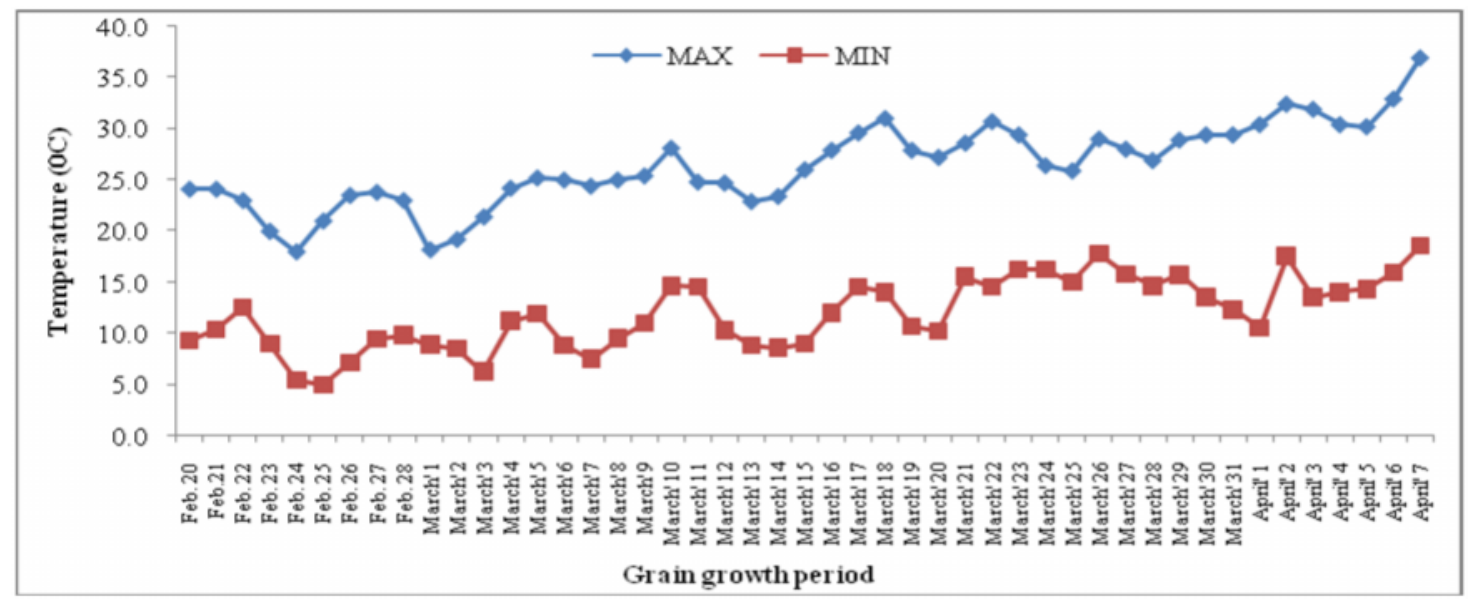

Fig.2 Mean performance of 40 genotypes w.r.t. biological and grain yield vs harvest index

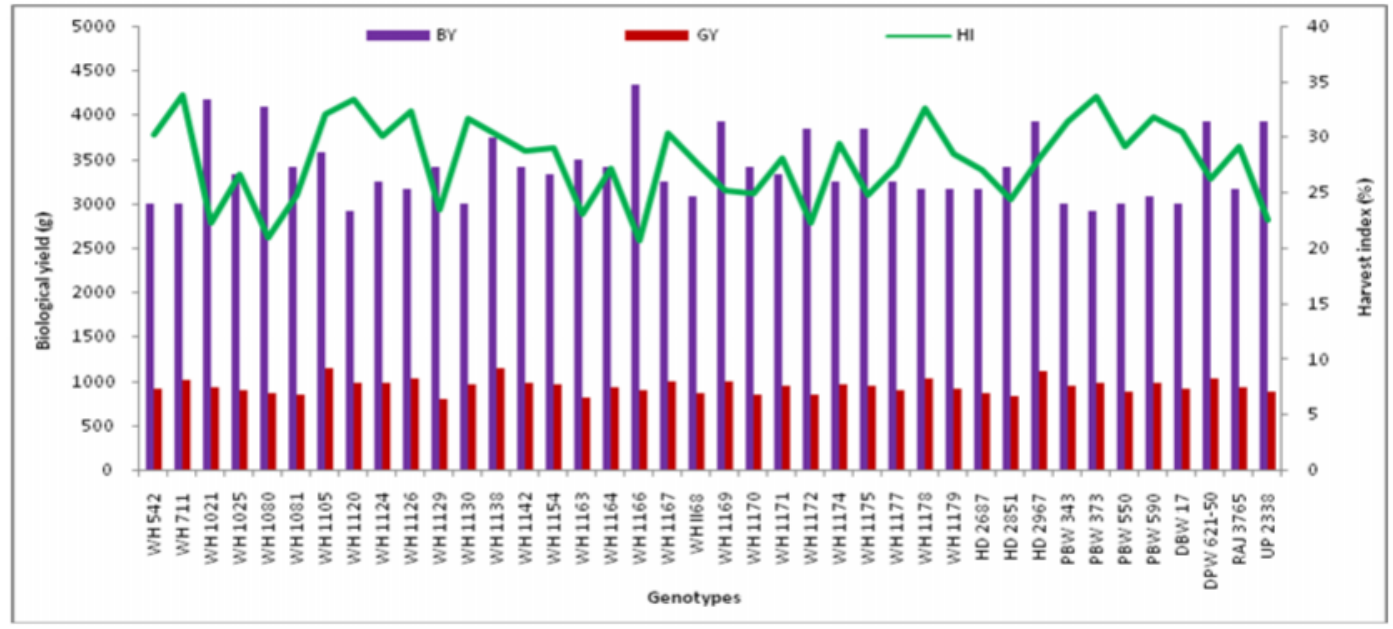

Fig.3 Graphical representation of grain growth rate vs 1000 grain weight

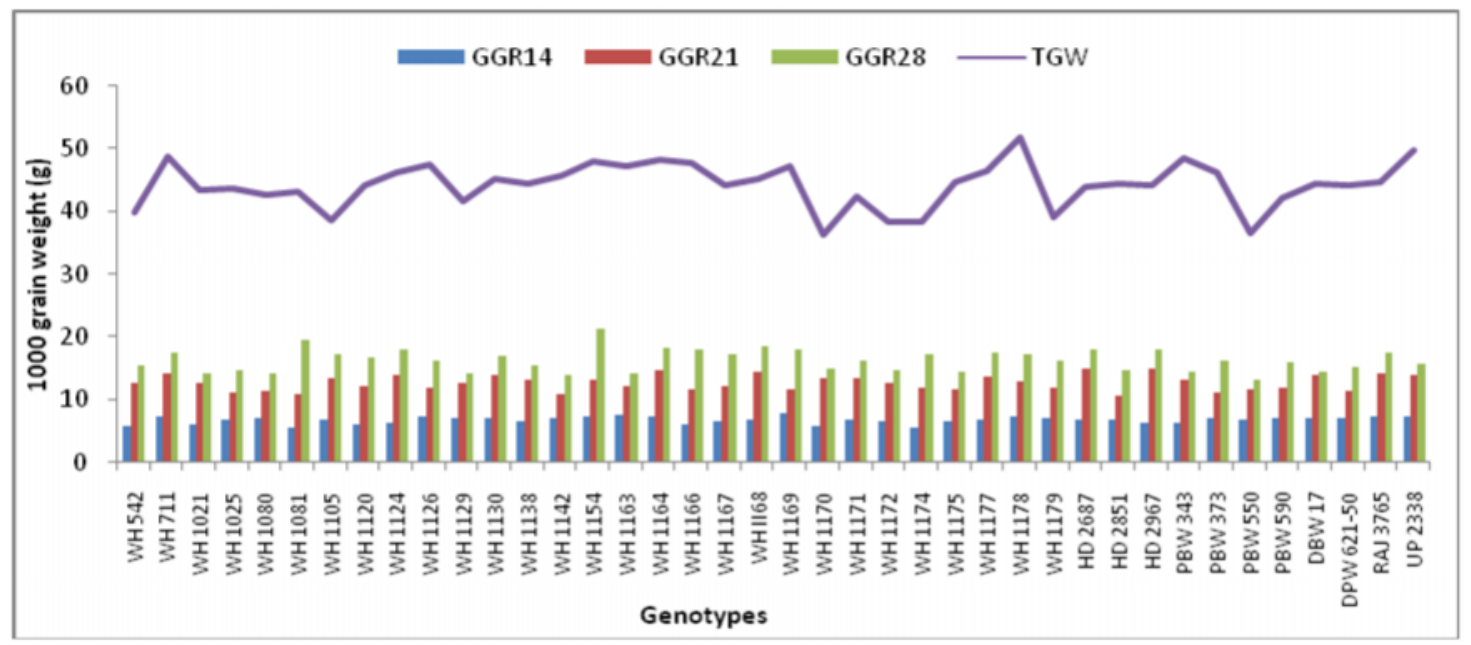


Table.1 List of genotypes along with their pedigree

\begin{tabular}{|c|c|c|}
\hline Sr. No. & Genotypes & Pedigree \\
\hline 1 & WH 542 & JUPATECO/BLUEJA/URES \\
\hline 2 & WH 711 & ALD 'S'/HAU//HD2285/3/HFW-17 \\
\hline 3 & WH 1021 & NYOT95(GW296)/SONAK \\
\hline 4 & WH 1025 & C591/PBW231 \\
\hline 5 & WH 1080 & $\mathrm{PRL} / 2 * \mathrm{PASTOR}$ \\
\hline 6 & WH 1081 & PBW65/2*PASTOR \\
\hline 7 & WH 1105 & MILAN/S87230//BABAX \\
\hline 8 & WH 1120 & PRL/2*PASTOR \\
\hline 9 & WH 1124 & MUNIA/CHTO//AMSEL \\
\hline 10 & WH 1126 & WBLL1*2/VIVITSI \\
\hline 11 & WH 1129 & CS/TH.CS//3*PVN/3/MIRLO/BUC/4/MILAN/5/TILHI \\
\hline 12 & WH 1130 & PRL/2*PASTOR/4/CHOIX/STAR/3/HE1*CN079 \\
\hline 13 & WH 1138 & PBW65*2/PASTOR \\
\hline 14 & WH 1142 & CHEN/Ae.sq (TAUS)//FCT/3/2*WEAVER \\
\hline 15 & WH 1154 & WH337/HD2255//RAJ3077 \\
\hline 16 & WH 1163 & HPW42/WH542 \\
\hline 17 & WH 1164 & RL6043/4*NAC//2*PASTOR \\
\hline 18 & WH 1166 & HD29/*WEAVER/3/VEE/PJN//2*WEAVER/3/VEE/PJN//2*TUI/4/MILAN \\
\hline 19 & WH 1167 & WEAVEAR/VIVISI/3/C80.1/3*BATAVIA//2*WBLLI \\
\hline 20 & WH II68 & ATTILA*2//CHIL/BUC*2/3/KUKUNA \\
\hline 21 & WH 1169 & KLDR/PEWITI/MILAN/DUCULA \\
\hline 22 & WH 1170 & LERKE/5/KAUZ/3/MYNA/VUL//BUC/FLK/4/MILLAN/6PROGRESOF2007 \\
\hline 23 & WH 1171 & MILAN//PRL/2*PASTOR/4/CROC_1/AE.SQ(213)//PGO/3/BAV92 \\
\hline 24 & WH 1172 & KLDR/PEWIT//MILAN/DUCULA \\
\hline 25 & WH 1174 & FILIN/IRENA/5/CNDOR/R143/ENIE/MEXI_2/3Ae.Sq/4/ \\
\hline 26 & WH 1175 & FILIN/2*PASTOR//BERKUT/3/PASTOR/2*SITTA \\
\hline 27 & WH 1177 & HP1744/PBW443 \\
\hline 28 & WH 1178 & CS//TH.86/3*PVN/3/MIRLO/BUC/4/MILAN/5/TILHI \\
\hline 29 & WH 1179 & OASIS/SKAUZ//4*BCN/3/3*PASTOR \\
\hline 30 & HD 2687 & CPAN2009/HD2329 \\
\hline 31 & HD 2851 & CPAN3004/WR426//HW2007 \\
\hline 32 & HD 2967 & ALD/CUC//URES/HD2160/HD2278 \\
\hline 33 & PBW 343 & ND/VG9144//KAL//BB/3//YCO 'S'/4/VEE\#5 'S’ \\
\hline 34 & PBW 550 & WH594/RAJ3856//W485 \\
\hline 35 & PBW 590 & WH594/RAJ3814//W485 \\
\hline 36 & PBW 373 & ND/VG9144//KAL//BB/3//YCO 'S'/4/VEE\#5 'S’ \\
\hline 37 & DBW 17 & CMH79A.95/3*CN079//RAJ3777 \\
\hline 38 & DPW 621- 50 & KAUZ//ALTAR84/AOS/3/MILAN/KAUZ/4/HUITES \\
\hline 39 & RAJ 3765 & HD 2402/VL639 \\
\hline 40 & UP 2338 & UP368/VL421//UP262 \\
\hline
\end{tabular}


Table.2 Analysis of variance (ANOVA) for different morpho-physiological and seed vigour traits in wheat

\begin{tabular}{|c|c|c|c|c|c|c|c|c|c|c|c|c|c|c|c|c|}
\hline \multirow{2}{*}{$\begin{array}{l}\text { Source of } \\
\text { variation }\end{array}$} & \multirow{2}{*}{$\begin{array}{l}\text { Degree of } \\
\text { freedom }\end{array}$} & \multicolumn{15}{|c|}{ Mean Sum of Squares } \\
\hline & & $\mathrm{DH}$ & DA & $\mathrm{PH}$ & FL & FB & $\begin{array}{l}\text { FL } \\
\text { A }\end{array}$ & $\mathrm{T}$ & SL & SW & SPS & GPS & GW & GL & GB & $\begin{array}{l}\text { TG } \\
W\end{array}$ \\
\hline Replications & 2 & 0.23 & 0.76 & 0.21 & 1.59 & 0.001 & 5.66 & 2.21 & 0.03 & 0.03 & 1.31 & 6.79 & 0.013 & 0.04 & 0.06 & 4.03 \\
\hline Treatments & 39 & $55.14 * *$ & $50.41 * *$ & $\begin{array}{l}228 . \\
44 * *\end{array}$ & $\begin{array}{l}33.0 \\
1 * *\end{array}$ & 0.055 & $\begin{array}{l}95.8 \\
1 * *\end{array}$ & $\begin{array}{l}985 . \\
50 * *\end{array}$ & $\begin{array}{l}3.43 * \\
*\end{array}$ & 0.19 & $4.95 * *$ & $54.35 * *$ & $\begin{array}{l}0.096 * \\
*\end{array}$ & 0.31 & 0.10 & $\begin{array}{l}38.6 \\
1 * *\end{array}$ \\
\hline Error & 78 & 0.86 & 0.91 & 3.44 & 0.84 & 0.004 & 3.74 & 5.51 & 0.05 & 0.01 & 0.34 & 2.66 & 0.007 & 0.01 & 0.01 & 2.92 \\
\hline
\end{tabular}

\begin{tabular}{|c|c|c|c|c|c|c|c|c|c|c|c|c|c|c|c|c|c|}
\hline \multirow{2}{*}{$\begin{array}{l}\text { Source of } \\
\text { variation }\end{array}$} & \multirow{2}{*}{$\begin{array}{l}\text { Degree of } \\
\text { freedom }\end{array}$} & \multicolumn{16}{|c|}{ Mean Sum of Squares } \\
\hline & & BY & GY & $\mathrm{HI}$ & $\begin{array}{l}\text { GG } \\
\text { R14 }\end{array}$ & $\begin{array}{l}\text { GG } \\
\text { R21 }\end{array}$ & $\begin{array}{l}\text { GG } \\
\text { R28 }\end{array}$ & GM & SLg & SD & V-I & V-II & $\mathrm{Sd}$ & SH & Dr. H & $\mathrm{FE}$ & FS \\
\hline $\begin{array}{l}\text { Replicatio } \\
\text { ns }\end{array}$ & 2 & $\begin{array}{l}116145 . \\
83\end{array}$ & $\begin{array}{l}2646.7 \\
0\end{array}$ & 2.35 & $\begin{array}{l}0.0 \\
04\end{array}$ & $\begin{array}{l}0.03 \\
0\end{array}$ & $\begin{array}{l}0.07 \\
4\end{array}$ & 2.86 & 0.16 & 3.33 & $\begin{array}{l}3307.8 \\
3\end{array}$ & $\begin{array}{l}151764.5 \\
9\end{array}$ & $\begin{array}{l}0.0 \\
02\end{array}$ & 1.01 & 0.02 & $\begin{array}{l}0.0 \\
1\end{array}$ & 0.31 \\
\hline $\begin{array}{l}\text { Treatmen } \\
\text { ts }\end{array}$ & 39 & $\begin{array}{l}426161 . \\
85 * *\end{array}$ & $\begin{array}{l}20589 . \\
30 * *\end{array}$ & $\begin{array}{l}40.7 \\
5 * *\end{array}$ & $\begin{array}{l}0.8 \\
71\end{array}$ & $\begin{array}{l}4.53 \\
5 * *\end{array}$ & $\begin{array}{l}9.39 \\
7 * *\end{array}$ & $\begin{array}{l}14.5 \\
1 * *\end{array}$ & $\begin{array}{l}2.85 * \\
*\end{array}$ & $\begin{array}{l}385 . \\
49 * *\end{array}$ & $\begin{array}{l}43003 . \\
71 * *\end{array}$ & $\begin{array}{l}4166930 . \\
53 * *\end{array}$ & $\begin{array}{l}0.0 \\
69\end{array}$ & $\begin{array}{l}28.7 \\
6 * *\end{array}$ & $\begin{array}{l}22.21 * \\
*\end{array}$ & $\begin{array}{l}0.3 \\
6\end{array}$ & $\begin{array}{l}80.5 \\
9 * *\end{array}$ \\
\hline Error & 78 & $\begin{array}{l}39222.7 \\
6\end{array}$ & $\begin{array}{l}2035.3 \\
0\end{array}$ & 1.81 & $\begin{array}{l}0.0 \\
29\end{array}$ & $\begin{array}{l}0.09 \\
4\end{array}$ & $\begin{array}{l}0.08 \\
1\end{array}$ & 2.54 & 0.15 & 3.58 & $\begin{array}{l}2349.3 \\
9\end{array}$ & 72077.01 & $\begin{array}{l}0.0 \\
03\end{array}$ & 0.36 & 0.25 & $\begin{array}{l}0.0 \\
3\end{array}$ & 4.10 \\
\hline
\end{tabular}


Table.3 Phenotypic correlation coefficients among different physio-morphological traits of wheat

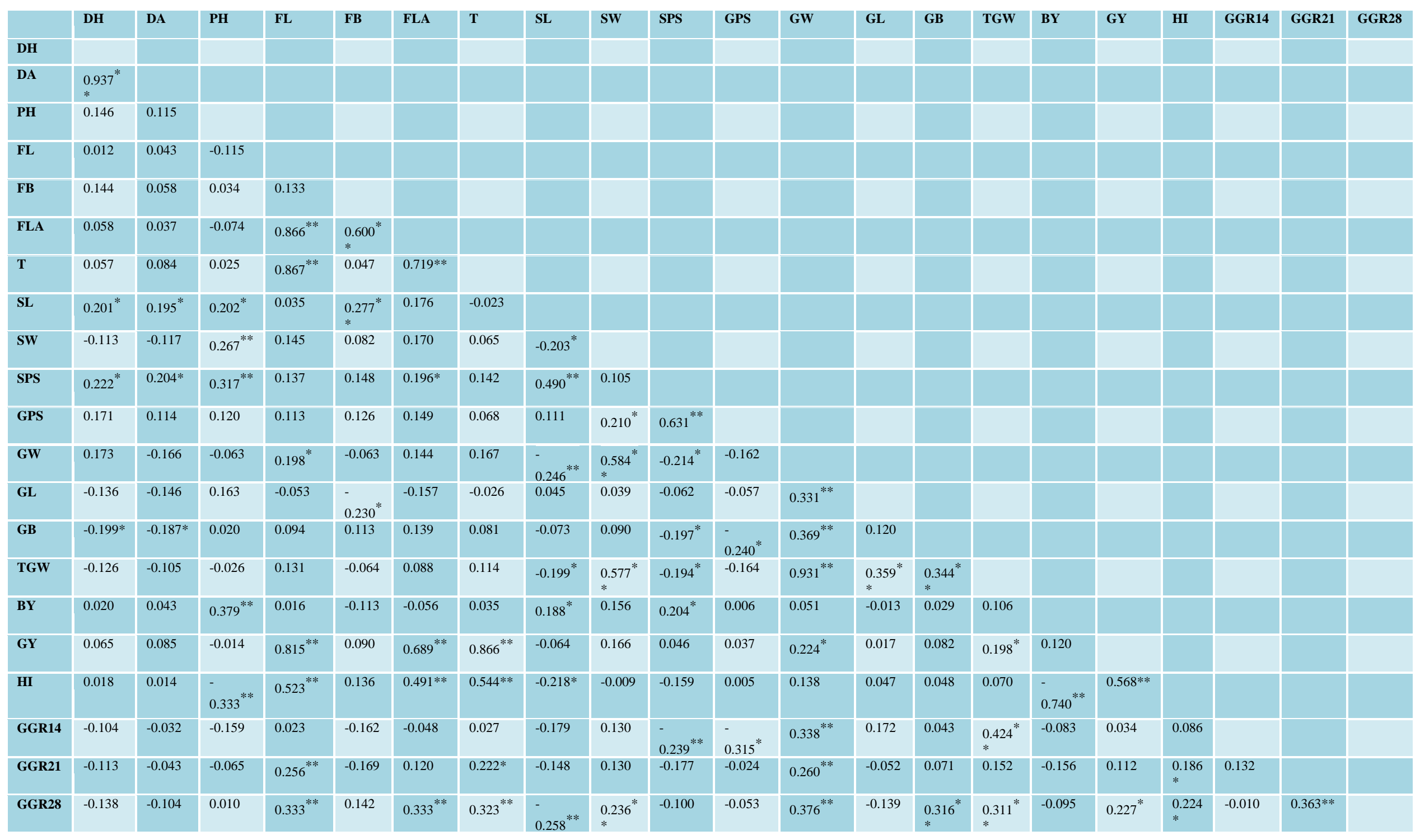


Table.4 Phenotypic correlation coefficients among yield and seed quality parameters

\begin{tabular}{|c|c|c|c|c|c|c|c|c|c|c|c|c|}
\hline & BY & GY & GM & SLg & SD & V-I & V-II & Sd & SH & Dr. H & $\mathbf{F E}$ & FS \\
\hline \multicolumn{13}{|l|}{ BY } \\
\hline GY & 0.120 & & & & & & & & & & & \\
\hline GM & 0.171 & -0.062 & & & & & & & & & & \\
\hline SLg & -0.098 & $-0.200^{*}$ & $0.285^{* *}$ & & & & & & & & & \\
\hline SD & 0.123 & 0.097 & $0.214^{*}$ & -0.007 & & & & & & & & \\
\hline V-I & -0.005 & $-0.181^{*}$ & $0.658^{* *}$ & $0.909^{* *}$ & 0.087 & & & & & & & \\
\hline V-II & 0.156 & 0.072 & $0.457^{* *}$ & 0.071 & $0.966^{* *}$ & $0.254^{* *}$ & & & & & & \\
\hline $\mathrm{Sd}$ & 0.079 & -0.143 & $0.207^{*}$ & 0.119 & -0.068 & $0.186^{*}$ & -0.007 & & & & & \\
\hline SH & 0.036 & -0.168 & 0.033 & $-0.388^{* *}$ & 0.014 & $-0.292^{* *}$ & 0.022 & 0.018 & & & & \\
\hline Dr. H & 0.052 & -0.036 & -0.089 & $-0.261^{* *}$ & -0.057 & $-0.245^{* *}$ & -0.076 & 0.047 & $0.639^{* *}$ & & & \\
\hline FE & -0.016 & -0.167 & $0.675^{* *}$ & $0.203^{*}$ & $0.329^{* *}$ & $0.453^{* *}$ & $0.480^{* *}$ & $0.203^{*}$ & 0.122 & -0.130 & & \\
\hline FS & 0.071 & -0.080 & 0.027 & $0.265^{* *}$ & $0.369^{* *}$ & $0.219^{*}$ & $0.345^{* *}$ & -0.024 & 0.075 & 0.122 & $0.180^{*}$ & \\
\hline
\end{tabular}

*significant at 5 per cent; **Significant at 1 per cent

BY: Biological yield (g); GY: Grain yield (g); GM: Germination\%; SLg: Seedling length (cm); SD: Seed dry weight $\left(\mathrm{g} \times 10^{-3}\right)$ V-I: Vigour index -I; V-II: Vigour index-II; Sd: Seed density(g/cc); SH: Straight plant height $(\mathrm{cm})$; Dr. H: Plant drooping height $(\mathrm{cm})$; FE: Field emergence index; FS: Seedling establishment $(\%)$.

The negative association of plant height with harvest index $\left(-0.333^{* *}\right)$ is due to the fact that an increase in plant height leads lodging, thereby decreasing the grain yield.

Flag leaf length was positively associated with flag leaf area $\left(0.866^{* *}\right)$, number of tillers per meter $(0.867 * *)$, grain weight per spike $(0.198 *)$, harvest index $(0.523 * *)$, grain growth rate at 21 days $\left(0.256^{* *}\right)$ and 28 days (0.333).

Grain weight per spike was positively correlated with grain length $\left(0.331^{* *}\right)$, grain breadth $\left(0.369^{* *}\right), \quad 1000$ grain weight $\left(0.931^{* *}\right)$, grain growth rate at 14,21 and 28 days $\quad\left(0.338^{* *}, \quad 0.260^{* *}, \quad 0.376^{* *}\right.$, respectively). Selection of these characters will increased the grain yield. Germination percentage (Table 5) showed positive correlation with seedling length $\left(0.285^{* *}\right)$, seedling dry weight $(0.214 *)$, vigour index-I $\left(0.658^{* *}\right)$, vigour index-II $\left(0.457^{* *}\right)$, seed density $\left(0.207^{*}\right)$ and field emergence index $\left(0.675^{* *}\right)$, which indicated that by increasing these attributes, germination percentage will be increased.
The two stages viz. seedling emergence and grain growth rate influence the grain yield in NWPZ. Seedling emergence can be improved by increasing the germination percentage and vigour index-II.

Grain growth rate is affected by days to $50 \%$ heading and grain filling rate. Selection for medium days to $50 \%$ heading (93-98 days) and medium maturity (140days) is best for developing high yielding genotypes for normal sown condition of the NWPZ of India.

\section{References}

Anonymous, Food and Agriculture Organization of the United Nations. 2017 (Available http://www.indiastat.com/agriculture/2/foodg rains/17180/wheat/17195/stats.aspx.).

Bhutta W M, Role of some agronomic traits for grain yield production in wheat (Triticum aestivum L.) genotypes under drought conditions. Revista UDO Agricola., 2006, 6, p 11-19.

Bhutto A H, Rajpar A A, Kalhoro S A, Ali A, Kalhoro F A, Ahmed M, Raza S, Kalahari N A, Correlation and regression analysis for yield traits in wheat (Triticum aestivum L.) genotypes. Nat.Sci. 2016, 8 p 96-104 
Bidinger $\mathrm{F}$, Musgrave $\mathrm{R} \mathrm{B}$, Fischer $\mathrm{R} \mathrm{A}$, Contribution of stored pre-anthesis assimilate to grain yield in wheat and barley. Nature. 1997, 70 p 431-433.

Cruz-Aguado J A, Reyes F, Rodes R, Perez I P, Dorado $\mathrm{M}$, Effect of source to-sink ratio on partitioning of dry matter and 14Cphotoassimilates in wheat during grain filling. Annals of Botany. 1999, 83 p 655-665.

Dias A S, and Lidon F C, Evaluation of grain filling rate and duration in bread and durum wheat, under heat stress after anthesis. $J$. Agron. Crop Sci. 2009, 195 p 137-147.

Evans L T, Wardlaw F T, Fischer, R A, Wheat. In L. T. Evans (Ed.), Crop Physiology: Some Case Histories. Cambridge: Cambrideg University Press, 1975

Fisher R A, Understanding the physiological basis of yield potential in wheat. J. Agric. Sci. 2007, 145 p 99-113.

Hasan M A, and Ahmed J U, Kernel growth physiology of wheat under late planting heat stress, J. Natl. Sci. Foundn. Sri Lanka. 2005, 33 p 193-204.

Kumar V, Sharma P K, Kumar H, Gupta V, Studies of variability and association of yield with some agromophological characters in bread wheat (Triticum aestivum L.). Indian J. Agric. Res. 2013, 48 p 429-436.

Laxman, Singh V, Solanki Y P S, Redhu A S, Phenological development, grain growth rate and yield relationships in wheat cultivars under late sown condition. Ind. J Plant Physio. 2014, 19 p 222-229.

Likhachev B S, Some problems of laboratory seed germination and field emergence of cereals. (In Russian). Byulleten' Vsesoyuznogo Ordena Lenina Instituta Rastenievodstva imeni N. I. Vavilova 1973, 33 p 24-33.

Ma, Y Z, MacKown C T, Van Sanford D A, Sink manipulation in wheat: Compensatory changes in kernel size. Crop Science. 1990, $30 \mathrm{p}$ 1099-1105.

Nukasani V, Potdukhe N R, Bharad S, Deshmukh S, Shinde S M, Genetic variability, correlation and path analsysis in wheat. $J$. Wheat Res. 2013, 5 p 48-51.

Rauf M, Munir M, UI-Hassan M, Ahmed M, Afzai M, Performance of wheat genotypes under osmotic stress at germination and early seedling growth stage. Afri J Biotech. 2007, 8 p 971-975.

Sanchez A C, Subudhi P K, Rosenow D T, Nguyen H T, Mapping QTLs associated with drought resistance in sorghum (Sorghum bicolor L. Moench). Plant Mol. Bio. 2002, 48 p 713-726.

Slafer G A, and Savin R, Source-sink relationships and grain mass at different positions within the spike in wheat. Field Crops Research, 1994, 37 p 39-49.

Tewolde H, Fernandez C J, Erickson C A, Wheat cultivars adapted to post heading high temperature stress. J. Agron. Crop Sci. 2006, 192 p 111-120.

Wang X, Cai J, Liu F, Jin M, Yu H, Jiang D, Wallenweber B, Dai T, Cao W, Pre-anthesis high temperature accumulation alleviates the negative effect of post anthesis heat stress on stem stored carbohydrates remobilization and grain starch accumulation in wheat. J. Plant Physiol. 2012, 55 p 331-336.

Whan B R, Carlton G P, Anderson W K, Potential for increasing rate of grain growth in spring wheat. I. Identification of genetic improvements. Aust. J. Agric. Res. 1996, 47 p $17-31$.

Yari L, Aghaalikani M, Khazaei F, Effect of seed priming duration and temperature on seed germination behaviour of bread wheat (Triticum aestivum L). ARPN J. Agric. Biol. Sci. 2010, 5 p 1-6.

\section{How to cite this article:}

Kavita Rani, Vikram Singh, V. S. Mor, M. S. Dalal and Ram Niwas. 2018. Phenological Development, Grain Growth Rate, Seedling Vigour and Yield Relationships in Wheat Cultivars under Normal Sown Irrigated Conditions. Int.J.Curr.Microbiol.App.Sci. 7(06): 3230-3238. doi: https://doi.org/10.20546/ijcmas.2018.706.380 